\title{
SABERES, FAZERES E MEMÓRIA COLETIVA: A TRAJETÓRIA SOCIAL DE BARBEIROS E BARBEIRAS DA REGIÃO CENTRAL DE PORTO ALEGRE (RS)
}

\author{
Pedro Paulo de Miranda Araújo Soares ${ }^{1}$
}

\section{Introdução}

Este trabalho tem como tema as transformações das relações de trabalho no mundo urbano, tensionando a prática de um ofício na cidade com as modificações que a urbe sofre ao longo do tempo. Partindo da "memória coletiva" (Halbwachs, 2006) de barbeiros e barbeiras que trabalham no Centro de Porto Alegre, pretendo problematizar os saberes e fazeres deste ofício, examinando as redes sociais de ingresso na profissão e a trajetória social ligada ao trabalho dos interlocutores. Assim, a pesquisa procura articular as "artes de fazer" (Certeau, 1994) de trabalhadores com a memória de uma cidade que se transforma ao longo do tempo, o que resulta em uma discussão sobre os impactos de fenômenos como a industrialização e urbanização da sociedade brasileira sobre as práticas de profissões consideradas tradicionais, tal como a de barbeiro ou barbeira.

Este trabalho busca dialogar com a proposta de uma "etnografia da duração" (Eckert e Rocha, 2001), privilegiando, portanto, as narrativas dos interlocutores sobre suas experiências na cidade e a observação de suas práticas, gestos e saberes cotidianos relacionados ao seu trabalho. Nestes estudos sobre "memória coletiva" (Halbwachs, 2006) de grupos urbanos, os interlocutores narram seus itinerários na urbe e acomodam as suas experiências individuais e coletivas na trajetória da cidade. É por meio desse esforço de pensarem a si mesmos no tempo que os sujeitos constroem uma "duração" (Eckert e Rocha, 2010) de suas práticas e vivências em um tempo que é descontínuo, mas cuja unidade é construída nas narrativas da relação destes sujeitos com o meio urbano.

Para este paper foram selecionados, portanto, três interlocutores cujas trajetórias permitem pensar sobre uma experiência comum do exercício da profissão de barbeiro na cidade de Porto Alegre, ao mesmo tempo em que apontam para diferentes configurações de redes sociais que tornam cada um bastante singular em sua trajetória de trabalho e

\footnotetext{
${ }^{1}$ Universidade Federal do Rio Grande do Sul, Brasil.
} 
em sua relação com a cidade. Estes interlocutores são Dona Geci (73 anos), Seu Renato (62 anos) e Joel (39 anos).

\section{Saberes e Fazeres}

O ofício de barbeiro ou barbeira é marcado por um conjunto de "técnicas corporais" (Mauss, 1978: 209) que não se limitam ao exercício de um gesto ou movimento específico de uma prática profissional. Como afirma Denis Chevalier (1991: 7), um "saber-fazer" implica mais do que o domínio de um gesto singular, sendo antes o conjunto de competências adquiridas, incorporadas e transmitidas que se manifestam em tal ato técnico. Sendo assim, ontologicamente, um "saber-fazer" é anterior ao ato técnico. Estando "presente a todo instante na atividade técnica, [um "saber-fazer"] é imperceptível nas atividades físicas do indivíduo. Está ligada às suas capacidades de julgar, prever, dominar um processo técnico e as relações sociais a ele associadas"2 (Chevalier, 1991: 7).

Um “saber-fazer" é composto também pelas relações sociais que o antecedem e o integram, o que ressoa na proposta do autor de não apenas descrever as funções das práticas de um ofício, mas de contextualizá-lo em sua dimensão sociológica. Nesse sentido, a "memória do trabalhador" (Leite Lopes, 1976: 64) emerge como um elemento inalienável ao seu saber-fazer, uma vez que traz à tona o cenário e as redes de parentesco e sociabilidade por meio das quais o trabalhador se constituiu como tal. Desse modo, se faz necessário apresentar as trajetórias de trabalho dos interlocutores da pesquisa, assim com as "redes sociais" (Bott, 1976) de ingresso na profissão na tentativa de situar as experiências de barbeiros e barbeiras nos contextos das relações de trabalho no Brasil urbano.

Para Chevalier, um "saber-fazer" também é composto pelas relações sociais que o antecedem e o integram (1991: 7). Isto ressoa em uma das propostas deste autor: a de não apenas descrever as funções das práticas de um ofício, mas de contextualizá-lo em sua dimensão sociológica. Nesse sentido, minha participação no projeto "Trabalho e Cidade: etnografia da memória do trabalho na cidade moderno-contemporânea", desenvolvido dentro do Banco de Imagens e Efeitos Visuais (BIEV-UFRGS) durante os anos de 2010 e 2011 foi fundamental ao possibilitar que fossem debatidas questões teórico-metodológicas relativas ao trabalho de campo que eu vinha desenvolvendo na

\footnotetext{
${ }^{2}$ Tradução livre do francês.
} 
época. Quinzenalmente discutíamos acerca da construção de redes sociais (Bott, 1976) no processo de pesquisa e da importância de observarmos como nossos interlocutores se movimentam por estas redes e pelo mundo urbano em sua trajetória de formação profissional. Estas discussões se alinham aos estudos sobre memória coletiva e itinerários urbanos no mundo contemporâneo desenvolvidos por Eckert e Rocha (2001), pois de acordo com estas autoras, é justamente a partir dos gestos, performances, dramas, intrigas, laços sociais e sociabilidades dos habitantes que uma cidade se mostra aos pesquisadores (Eckert, 2010: 175).

Dessa forma, discutir sobre "saberes e fazeres" (Chevalier, 1991) - ao menos para o caso do artigo em questão - é buscar o desvelamento das relações sociais que operam na formação de um barbeiro ou barbeira em Porto Alegre. Estas relações, repletas de dramas, intrigas, alianças e rupturas compõem em si mesmas uma parcela memória da profissão na cidade, pois trazem à tona a experiência dos interlocutores a respeito de seu ingresso no mundo do trabalho de Porto Alegre. Desse modo, se faz necessário apresentar as "trajetórias sociais" (Leite Lopes, 1976: 15) - que no contexto do Projeto Trabalho e Cidade são chamadas de "trajetórias de trabalho" - destes trabalhadores, assim como as "redes sociais" (Bott, 1976) de ingresso no mundo do trabalho para situá-los nos contextos das relações de trabalho no Brasil urbano. É sobre estes aspectos do "saber-fazer" de barbeiras e barbeiros que se ocupa este artigo.

\section{Personagens, Redes Sociais e Trajetórias de Trabalho}

\section{Seu Renato}

Com 62 anos de idade e há 40 na profissão de barbeiro, seu Renato está aposentado, "apenas administrando", como ele gosta de dizer. Apesar de sua diabetes, ele trabalha de segunda a sábado na Barbearia Elegante ${ }^{3}$ (localizada na Rua Jerônimo Coelho próximo à Avenida Borges de Medeiros). Todo dia às sete da noite deixa a barbearia e vai ao culto na Igreja Universal que fica próxima à rodoviária no Centro de Porto Alegre. Chega em sua casa no bairro da Glória em Porto Alegre somente às onze da noite para dormir e recomeçar sua jornada de trabalho no dia seguinte.

\footnotetext{
${ }^{3}$ Este salão chama a atenção dos passantes pela sua beleza e requinte. Recentemente (2007) fora reformado e redecorado, sendo que ao seu lado foi construído um bistrô que é administrado pela esposa e pelo filho do proprietário da barbearia.
} 
Entre os interlocutores que conheci até o momento, Seu Renato é aquele que demonstrou maior prazer em narrar e dramatizar suas experiências. Em uma das primeiras tardes em que fui à barbearia revelei a Seu Renato que estava interessado em saber mais sobre a profissão de barbeiro, pois realizaria uma pesquisa sobre este assunto. Sentado em um mocho de madeira no vão entre duas poltronas de barbeiro, ele começou a tecer comentários mais gerais acerca da profissão, como "antes era melhor, hoje não tem mais tanto barbeiro como antigamente" e, de repente, encadeou a seguinte narrativa que eu não tive a oportunidade de registrar com o gravador, mas procurei reproduzir em meu diário de campo.

\author{
Meu pai me dizia: \\ - Filho, vá aprender uma profissão. Olhe o seu irmão, ele tá bem! \\ - Eu, ficar alisando cara de homem? Ah, não!
}

Eu era jovem, né, achava que tava por cima... Aí meu pai foi e disse: "Não quer estudar, então vai trabalhar!" Aí fui trabalhar. Procurei trabalho e fui trabalhando, arrumando empreguinho aqui, emprego ali, em empresa, mas nunca durava, dava três mês e eles me mandavam embora, diziam "olha, seu trabalho é muito bom, mas temos que fazer cortes". Aí comecei a pensar: "é, acho que tá na hora de eu aprender uma profissão, porque eu não paro em lugar nenhum”. Então eu entrei pro Senac.

Aí o meu pai ficou doente e uma vez eu fui fazer a barba dele e quando eu tava fazendo a barba dele, ele me disse:

- Meu filho, você vai ser um grande barbeiro!

Porque quando eu passava a navalha aqui, debaixo do nariz dele, que essa pele aqui ela é muito sensível, sabe? Quando eu passava a navalha aqui, não estourava a pele! E o meu pai me disse: "meu filho, você vai ser um grande barbeiro" e as lágrimas escorrendo dos olhos.

E desde ali passou 40 anos, teve altos e baixos, mas nunca, graça a Deus, nunca me faltou trabalho.

Na narrativa acima Seu Renato dramatiza a sua condição de jovem relutante em abraçar a profissão de barbeiro - a qual possui antecedentes familiares, já que seu irmão é do ramo - para posteriormente, diante de um evento crítico com a enfermidade do pai, ir ao encontro daquele que seria o inevitável de sua vocação. As palavras do pai moribundo, incapaz até de barbear a si mesmo, revestem-se da autoridade simbólica que Walter Benjamin (1996) identifica como própria àqueles narradores que estão à beira da morte. O jovem Renato vê seu emocionado pai profetizar o sucesso do filho e assim toma coragem para seguir adiante em sua carreira profissional. Esta carreira agora seria 
justificada a partir de uma espécie de mito de origem, como é configurado no episódio narrado.
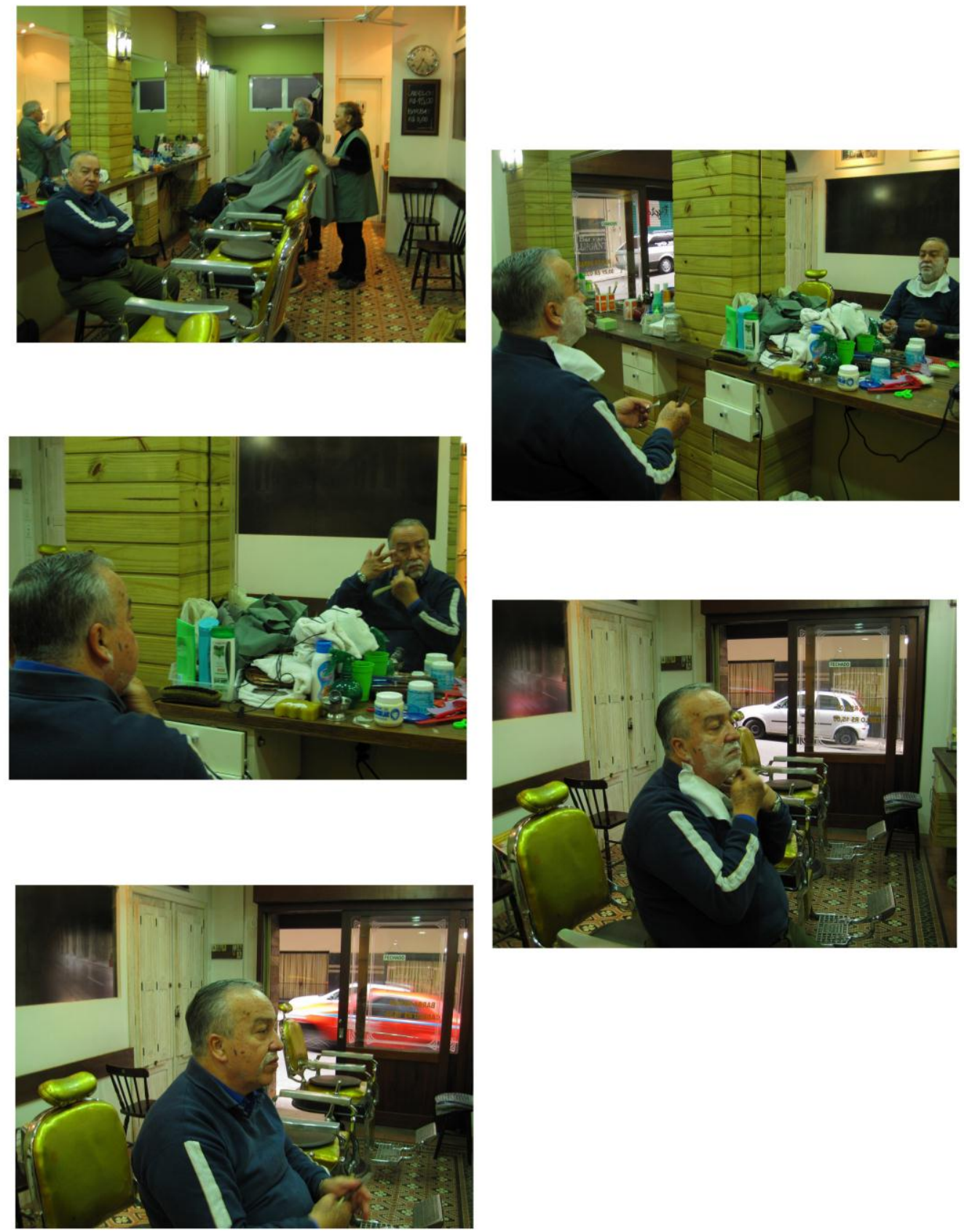

1. Seu Renato. Fotos de 2011 - autoria do autor. 
Antes, para o jovem Renato a especificidade da profissão - que também era a de seu irmão - estava ligada a expedientes que o jovem Renato enxergava como degradantes ou indignos na medida em que implicavam um contato muito próximo e até íntimo com pessoas do mesmo sexo, ou seja, "ficar alisando cara de homem”. Após o episódio com o pai, os estigmas relativos à profissão de barbeiro são re-significados. Agora, é a técnica que emerge como elemento redentor e determinante do ofício, sendo fundamental para a conversão de Seu Renato em um "grande barbeiro". Como o próprio narrador explicou durante seu relato, a sua aptidão profissional é confirmada quando ele, ainda no início de sua formação, executa de maneira perfeita um procedimento considerado delicado para a maioria dos barbeiros, deixando seu velho pai maravilhado. Assim, a narrativa de Seu Renato contribui para confirmar sua vocação e exaltar sua excepcionalidade enquanto profissional, justificando sua entrada no mundo do trabalho portoalegrense por meio da profissão de barbeiro.

Uma das virtudes de seu Renato enquanto narrador é a sua capacidade de divagar, devanear e fazer emergir uma história a partir de um simples comentário ou menção a um objeto da barbearia. Um desses casos ocorreu quando um amigo que me acompanhava na barbearia admirou-se das cadeiras de barbeiro bem conservadas do local. Essa foi a deixa para que Seu Renato irrompesse com uma narrativa que, naquele momento, não pareceu fazer o menor sentido. Não consegui realizar uma transcrição que se aproximasse do discurso direto de Seu Renato devido ao fato de ser um relato longo e aparentemente confuso. Portanto, a narrativa será representada como está no meu diário de campo, por meio do discurso indireto.

Seu Renato nos contou que, quando ainda estava no início de sua carreira de barbeiro, leu o anúncio de uma cadeira e de uma máquina elétrica de cortar cabelo por 900 cruzados. Ao mesmo tempo, foi avisado da existência um terreno à venda pelo mesmo valor na região da estrada para Viamão. O jovem aprendiz de barbeiro se viu em um dilema que, no entanto, foi resolvido com o surgimento de uma terceira possibilidade. Conta Seu Renato que nessa época trabalhava como porteiro em um edifício e lhe foi apresentada uma proposta que pareceu proveitosa naquele momento: a síndica ofereceu-lhe um cargo de zelador, acompanhado de um apartamento naquele mesmo prédio. Seu Renato recorda-se que, quando fez a primeira visita ao apartamento:

- Quando eu entrei naquele apartamento eu vi que ele tava novinho... Se eu te disser que aquele piso de madeira tava brilhando, o sinteko fez arder os meus olhos!

Só havia uma condição para que seu Renato conseguisse o emprego e o apartamento: ele deveria ser casado. 
Àquela altura de sua vida, Seu Renato já fazia o curso de barbeiro no SENAC e era noivo. O barbeiro conta que sua empregadora já sabia que ele estava noivo e então lhe disse que providenciasse o matrimônio, pois deveria se casar dentro de um mês se quisesse o emprego. Assim, o jovem Renato abriu mão do terreno de 900 cruzados e comprou a cadeira e a máquina que estavam à venda em uma barbearia na Avenida Salgado Filho.

Em um mês, casou-se e tomou posse do imóvel no prédio onde passou a ser zelador. Quando terminou o curso no SENAC foi trabalhar na Barbearia Elegante.

Tempos depois, Seu Renato foi procurar novamente um terreno nas proximidades de Viamão, pois segundo o barbeiro afirmou, ele e sua esposa procuravam um local mais calmo e com mais espaço para criarem os filhos que já estavam a caminho. Conta Seu Renato que, dois anos depois, um terreno nas mesmas imediações daquele que anteriormente custava 900 cruzados estava agora custando onze mil. Seu Renato tentou barganhar:

- Mas e à vista, quanto é que fica?

- Ah, aí à vista muda de preço!

- Quanto?

- Quatro m...

- É meu! - Gritou Seu Renato sem deixar o vendedor completar a frase.

Combinaram que seriam dois mil de entrada e mais dois mil a serem pagos no momento de entrega da escritura. Seu Renato mudou-se para a chácara onde criou seus filhos e viveu até certo tempo. No final da narrativa ele voltou-se a nós e refletiu sobre o sentido de suas palavras:

- Mas por quê que eu tô contando essa história? Pra vocês verem que se eu tivesse comprado o terreno, ele tinha multiplicado o valor. Enquanto que a cadeira, ela só se desvalorizou. Quando a gente não tem experiência, não sabe pensar olhando lá na frente... (Trecho de diário de campo, 25 de setembro de 2011).

A narrativa acima remete a parte da trajetória profissional de Seu Renato, que nasceu na região do Alto Taquari, no interior do Rio Grande do Sul. Esta história se refere a um momento em que o jovem Renato já saiu da casa de sua família e se encontra em Porto Alegre em busca de seu sustento. A temática do encontro com a vocação profissional também está presente, porque mesmo quando Seu Renato inicialmente trata a compra dos instrumentos da profissão - cadeira e a máquina - como equivocada ou precipitada, compreende-se depois que o terreno comprado por Seu Renato foi pago com os dividendos gerados pela cadeira e a máquina.

O terreno teve seu valor bruscamente multiplicado, mas mesmo assim Seu Renato foi capaz de comprá-lo com o dinheiro ganho por meio de seu trabalho. É certo que o terreno oferecido por 900 cruzados teria rendido muito mais capital à longo prazo, mas ele não traria, por si só, o sustento de Seu Renato e de sua família de forma imediata. O emprego de zelador, ao contrário, lhe garante moradia e a remuneração 
necessária para continuar o curso no SENAC ${ }^{4}$. Ao mesmo tempo a escolha da compra da cadeira e da máquina possibilita que ele disponha de um mínimo de capital incorporado para se lançar no mercado de trabalho após o término de seu curso profissionalizante.

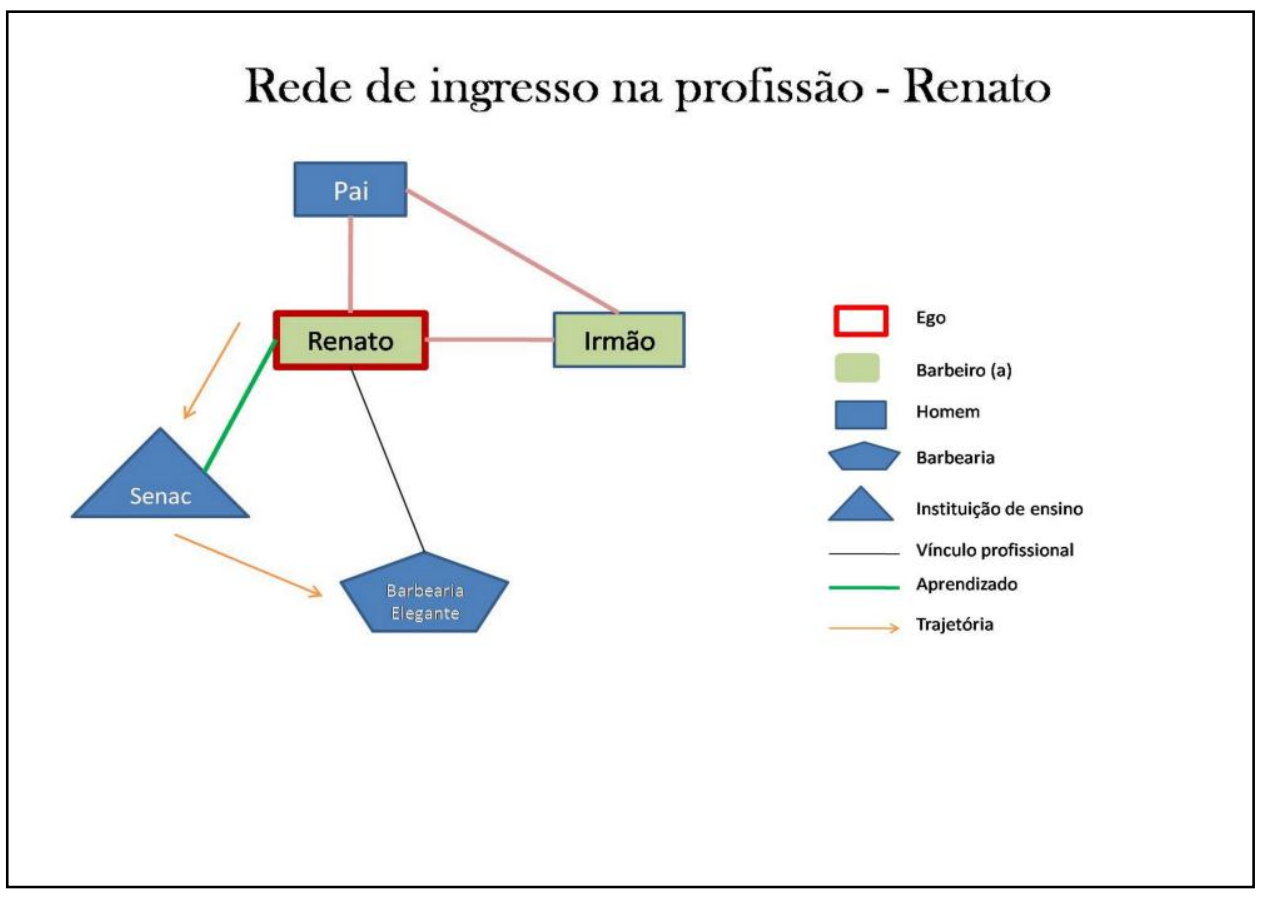

2. Ilustração de rede social - autoria do autor.

O relato do barbeiro também introduz outra problemática ao trazer à tona o papel do SENAC como a instituição de ensino formal pela qual Seu Renato teve que passar para poder ingressar no mercado de trabalho portoalegrense. Instituições formadoras como SENAC têm importância neste trabalho porque constituem parte das possíveis redes de relações sociais implicadas nos processos de aprendizado e ingresso em um ofício ou profissão. Seu Renato, por exemplo, precisou trabalhar para arcar com as despesas de um curso profissionalizante de barbeiros. No entanto, a importância do SENAC para a formação profissional do barbeiro Renato pode ser relativizada no que

\footnotetext{
${ }^{4}$ SENAC - Serviço Nacional de Aprendizagem Comercial.
} 
diz respeito às vicissitudes da prática cotidiana da profissão ao longo dos anos, como ele mesmo contou:

Aí achei melhor à noite aproveitar o tempo e entrei no SENAC. Entrei no SENAC, coisa e tal, e depois de um ano de SENAC a gente sai com noção de como começar uma profissão. Mas na realidade, o aperfeiçoamento vem no tempo. Perguntei depois pra um colega que tava trabalhando: "Em quanto tempo posso me considerar um profissional?" [O colega respondeu] "Olha, sem medo de errar: depois de vinte anos tu vai saber o que tu tá fazendo [risos]" E assim foi.

É bastante recorrente (baseando-me no que o trabalho etnográfico mostrou até agora) entre os barbeiros de Porto Alegre que estes realizem um curso no SENAC. No entanto, este tipo de curso mais parece ter como objetivo legitimar a condição do barbeiro diante do Estado - e, por conseguinte, dos colegas de trabalho e da clientela como alguém capaz de exercer a profissão, além de permitir a sua entrada como profissional em algum salão. No entanto, não se pode esquecer que o irmão mais velho de Seu Renato também era barbeiro. Dessa forma, não descarto a hipótese de que ao menos uma parte do aprendizado do jovem Renato também tenha começado dentro de sua própria casa.

\section{Dona Geci}

Quando retornei à Barbearia Elegante decidido a realizar uma pesquisa sobre os salões de barbeiros de Porto Alegre, surpreendi-me ao encontrar uma mulher atuando em uma profissão considerada essencialmente masculina como a de barbeiro. Em meus passeios pelo Centro já havia identificado mulheres trabalhando nas barbearias como manicures, cabeleireiras ou esteticistas. Mas Dona Geci (73 anos) era barbeira há bastante tempo e se identificava como tal. Nesta ocasião, Dona Geci cortou meu cabelo e assim o fez sucessivamente até sua aposentadoria no primeiro semestre de 2011.

Solícita sempre que pedia para fotografá-la trabalhando e receptiva para um bom bate-papo, Dona Geci era reticente em relação a falar sobre sua trajetória. Na única entrevista que me concedeu, fez questão para que fôssemos para o lado de fora da barbearia. Ali o som de sua voz frágil mal se sobrepunha ao ruído dos carros e ônibus que cruzavam Avenida Borges de Medeiros. Dessa forma, o pouco que sei sobre Dona Geci é o que chegou a mim por meio de conversas informais com a barbeira e pelas fofocas que ouvia no cotidiano da barbearia. 
Durante a entrevista, Dona Geci contou como começou na profissão:

Na profissão eu comecei com treze anos. Trabalhava numa casa de família e ela [a patroa] era cabeleireira. Quando eu terminava de fazer o serviço, era o trato: aí eu ficava olhando ela trabalhar. Aí passei um tempo, casei, vim pra Porto Alegre. E fazia uns dez anos que eu tava em Porto Alegre. Eu morava em Santa Cruz do Sul. Aí fui indo cada vez mais e passei a manicure. Fui manicure por uns vinte anos. Aí achei que manicure num tava, num tava mais bom de trabalhar que cabeleireiro, aí parei.

Como Dona Geci assinalou, começou sua carreira profissional na Barbearia Elegante como manicure ao seguir um anúncio de jornal que solicitava uma profissional desta área. Embora já soubesse cortar cabelos desde os trezes anos de idade, seu ingresso na barbearia elegante se dá conforme a hierarquia e a divisão de gênero do trabalho naquele espaço. Segundo a interlocutora, conseguiu chegar a barbeira devido à ação de um primo que também era barbeiro - assim como um de seus tios - e conhecia o presidente do sindicato da categoria na época. Assim, Dona Geci faz um curso profissionalizante de barbeiro no SENAC e é admitida na categoria graças à sua rede de relações composta por outros barbeiros e representantes políticos deste segmento profissional.

Em uma de nossas conversas eu lhe perguntei se os barbeiros homens que já trabalhavam no local não estranharam quando ela passou de manicure a barbeira do salão e ela me respondeu: "Eles não podiam fazer nada. Eu sempre me dei muito bem com o Ilson, ele sempre foi muito amigo meu". Dona Geci referia-se a Ilson Schambeck, o dono do salão que é um médico bioquímico, qual já tive a oportunidade de conhecer. Portanto, além dos contatos políticos e familiares, a barbeira ainda tinha uma boa relação com o dono do estabelecimento, o que facilitou sua guinada profissional dentro do local de trabalho. Quando ela diz "eles não podiam fazer nada", referindo-se aos colegas de trabalho, Dona Geci deixa entrever que sua mudança de profissão não se deu sem certa dose de conflito, o que é compreensível: ao tornar-se barbeira, ela teria saído de uma profissão "feminina" como a de manicure para uma "masculina" que seria a de barbeiro, transcendendo a divisão sexual do trabalho e as hierarquias dos papéis sociais de gênero dentro da barbearia. 


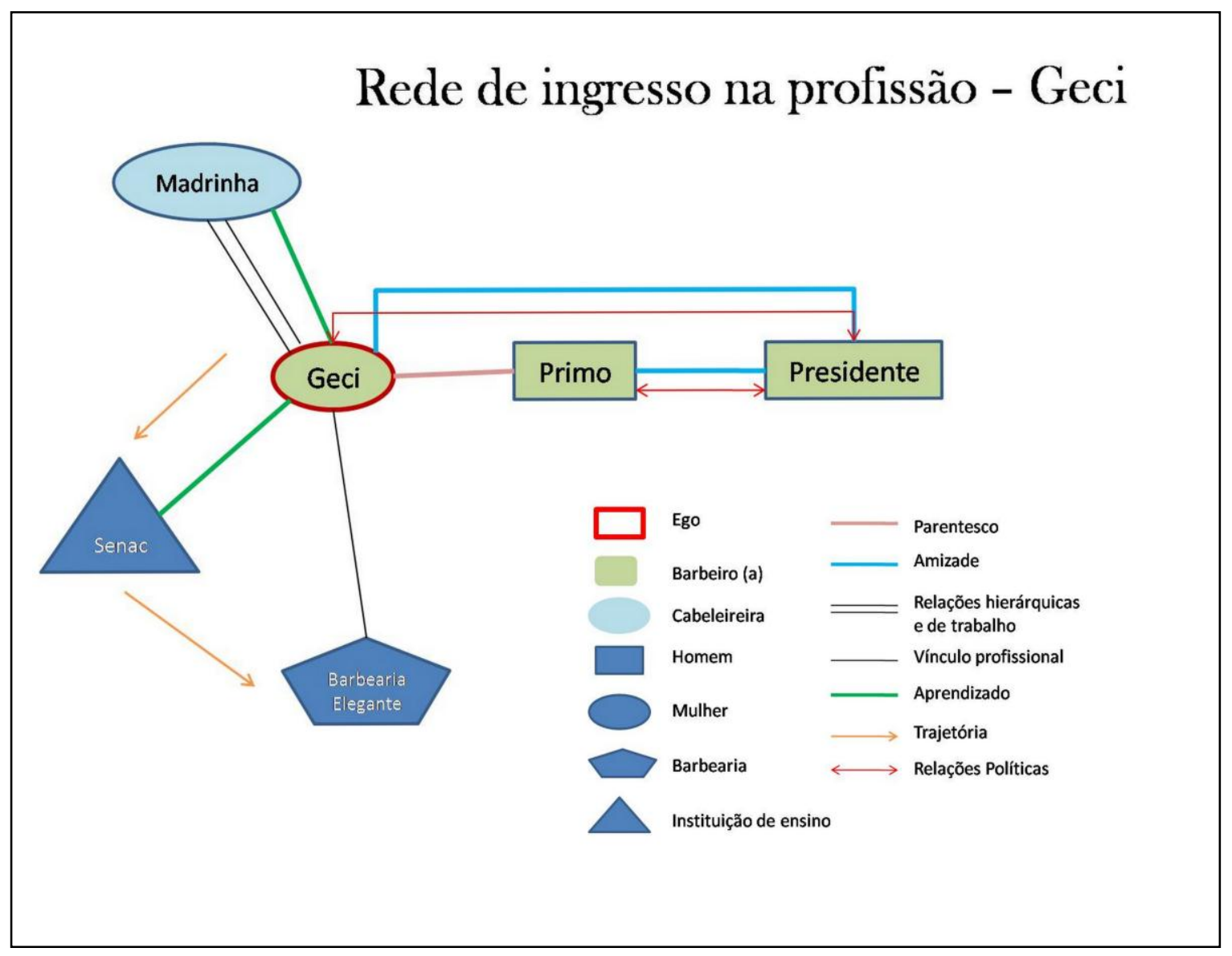

3. Ilustração de rede social - autoria do autor.

A presença de mulheres trabalhando nas barbearias hoje em dia pode ser interpretada como uma busca desses estabelecimentos por se adaptarem às exigências de mercado, oferecendo outros serviços além de "cabelo" e "barba" para competir com os modernos salões de beleza. Essa interpretação pressupõe a idéia de uma "descaracterização" das barbearias "tradicionais" que estariam cada vez mais próximas de acabar, tornando-se salões de beleza comuns. Uma hipótese sobre isso é a de que a presença de mulheres trabalhando nas barbearias diz respeito muito mais às redes de relações e às trajetórias de trabalho que possibilitam a sua presença neste local, do que a uma adaptação dos salões de barbeiros às demandas de mercado atuais. A trajetória de Dona Geci mostra que há 40 anos (se levarmos em conta que ela trabalhou como manicure por 20 anos e como barbeira por mais 20) já era possível encontrar mulheres trabalhando junto aos homens dentro das barbearias de Porto Alegre. Mesclando 
recordações pessoais com relatos de terceiros, Juremir Machado da Silva (1991) escreve sobre as antigas barbearias de Porto Alegre e em um dado momento de sua prosa se dedica às mulheres que trabalhavam nesses espaços:

Na rua Silva Só existia uma "barbeira", a dona Joaninha, que cortava o cabelo da molecada com aquelas máquinas manuais. Em cima de uma prateleira, além da tesoura, escova, navalha, havia um vidro de mercúrio e um de algodão. Ela invariavelmente enfiava a maquininha no couro cabeludo da gente e sempre voltávamos para casa aos prantos com a cabeça manchada de mercúrio e apenas um topete no alto da testa. Dávamos graças a Deus que ela não cortasse nosso pescoço com a navalha na hora daquela "aparadinha" na nuca. (Machado da Silva, 1991: 4344).

E um pouco adiante escreve sobre uma manicure que trabalhava em uma barbearia do bairro do Bom Fim:

$\mathrm{Na}$ frente da minha casa havia a barbearia do Floriano. Lá dentro, além dos barbeiros, trabalhava uma manicure. Os homens iam lá fazer as unhas e namoravam a "dona boa", como se dizia então. Eram longos romances, que faziam nós, meninos, entrando na adolescência, sonhar com os carinhos daquela manicure. (p. 44).

Este último trecho chama atenção para questões de gênero dentro da barbearia no que diz respeito à presença da uma mulher em um ambiente masculino, o que reflete um duplo tabu: o da mulher que exerce uma atividade tida como masculina e endereçada ao público masculino, bem como o tabu da mulher desacompanhada no espaço público (Okin, 2008: 311). Depois de um tempo frequentando a Barbearia Elegante entendi o porquê de Dona Geci ter me atendido naquele dia em que entrei na barbearia pela primeira vez, mesmo quando todos os outros barbeiros estavam disponíveis: ela me atendeu por conta de minha idade. A barbeira diz que grande parte de sua clientela é formada por homens mais jovens. Mas por quê? "Os velhos ficam querendo namorar comigo", confiou-me Dona Geci. Isso sugeria que sua permanência na barbearia não se dava sem constrangimentos relativos ao fato de ser mulher e tampouco sem uma tácita divisão sexual do trabalho. 

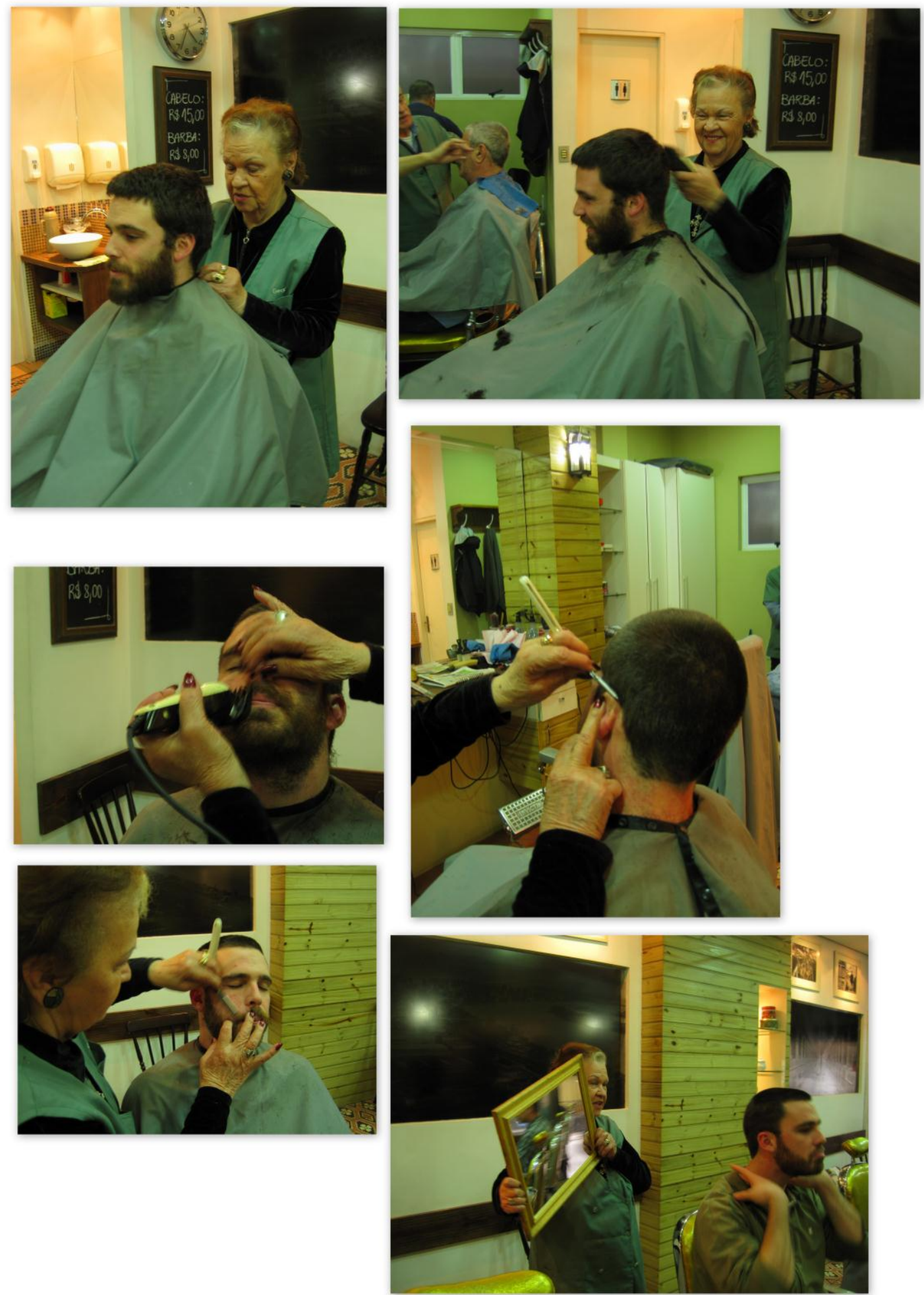

4. Dona Geci. Fotos de 2011 - autoria do autor. 
Joel

Indicado como um potencial interlocutor por um professor da universidade que é seu cliente há mais de 10 anos, Joel (39 anos) trabalha no Salão Santos e Cia., que se situa na Rua General Câmara (ou Rua da Ladeira), famosa por concentrar um grande número de lojas de livros usados e barbearias. Nesta pesquisa, Joel foi o primeiro profissional que conheci cujo pai também exercia o ofício de barbeiro. Na profissão há pouco mais de 20 anos, Joel nunca fez curso profissionalizante, algo que a maioria dos barbeiros que conheci em Porto Alegre sempre faz. Quando o conheci percebi que o recorte geracional que sua idade sugere, a camisa cor-de-rosa que usava, o brinco na orelha e as "luzes" nos seus cabelos apontavam para uma construção de masculinidade diferente da dos barbeiros com mais de 60 anos da Barbearia Elegante. A própria maneira com que Joel se define como profissional já coloca a possibilidade de se pensar outros arranjos relativos à vivência da profissão de barbeiro em Porto Alegre:

\footnotetext{
Cara, eu acho que, eu acho que tudo é momento. Eu gosto do que faço, né, acima de tudo gosto do que faço. O cliente hoje, ele que vai me dizer o que ele quer. Assim como eu posso me colocar, dependendo do cliente, como barbeiro, também pode chegar um cliente e eu me colocar como cabeleireiro. Vai muito do cliente. Né, às vezes se você pegar um cliente dos seus 19 anos 30, eu não posso me colocar como barbeiro, tenho que me colocar como cabeleireiro. Ele vai querer uma coisa mais moderna, um moicano disfarçado, desfiado, navalhado, mas também tenho aquele cliente que quer como barbeiro: aquele veinho que é meu cliente, aquele senhor que quer que eu corte o cabelo dele só na tesoura, faça uma barbinha só na navalha, tá entendendo? O local é que vai me determinar. Eu sou um barbeiro que me aperfeiçoei e me tornei um cabeleireiro masculino. Mas também não deixei de ser barbeiro.
}

Para Joel, a definição de sua identidade como trabalhador é relacional, dependendo do cliente que ele atende no momento, de suas preferências em relação ao tipo de barba ou de cabelo que deseja. A sua condição ambígua de cabeleireiro masculino/barbeiro evidencia algumas das formas pelas quais o ofício de barbeiro se transforma e assim continua a durar na cidade de Porto Alegre. Mas não é apenas isso. Ao discutir sobre um ofício como o de barbeiro, é preciso considerar que estes são portadores de um "saber-fazer" artesanal que remete a um "saber-viver" (Chevalier, 1989: 9). Este "savoir-faire" conserva uma aura própria às coisas do sagrado e por isso seria mantido quase como em segredo, compartilhado dentro da comunidade étnica ou entre pais e filhos. Portanto, essa identidade profissional ambivalente de Joel está relacionada à maneira como uma tradição familiar é acomodada dentro da trajetória do interlocutor. 

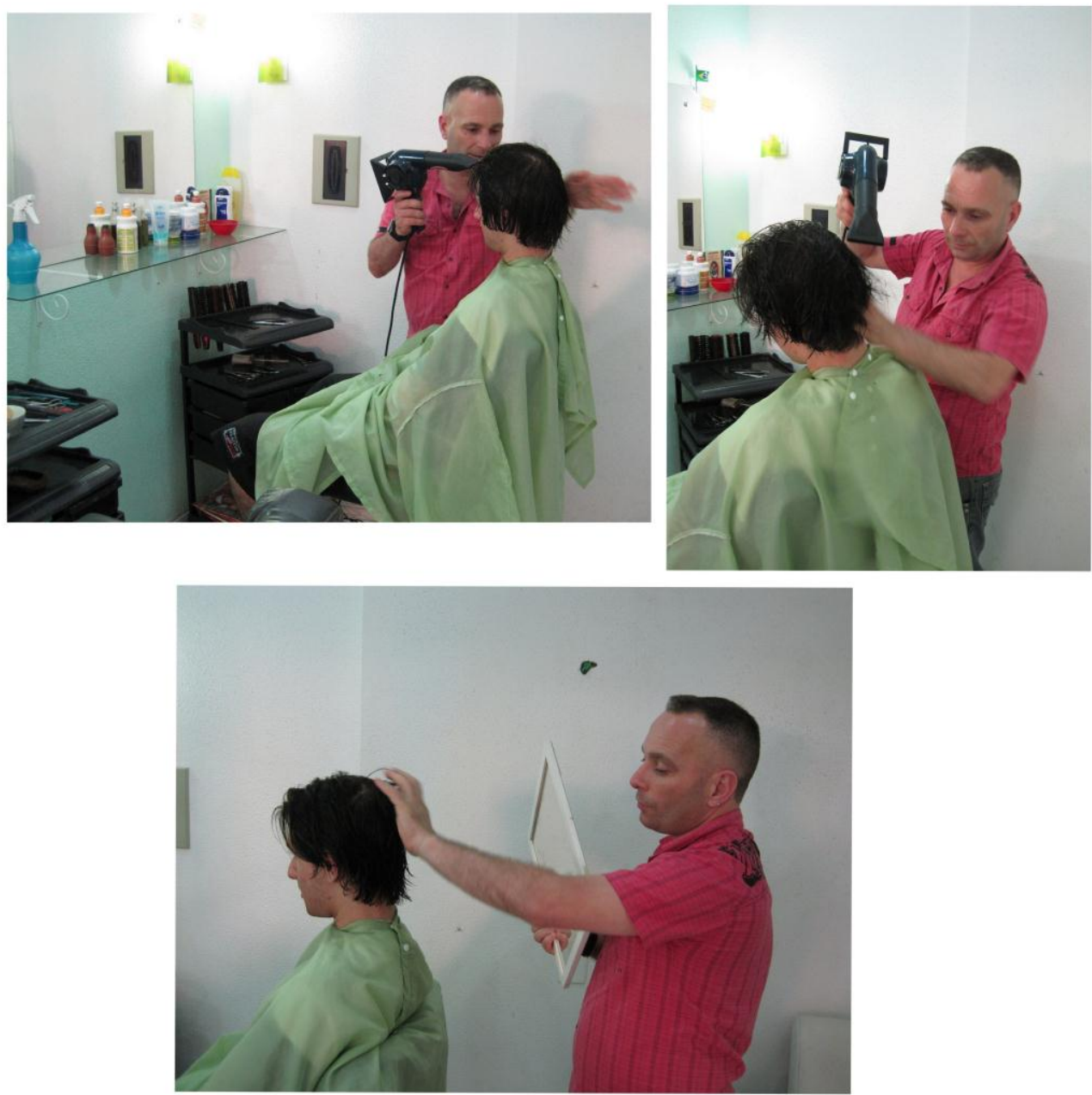

5. Joel. Fotos de 2011 - autoria do autor.

Joel começou a trabalhar na barbearia do pai no bairro portoalegrense de Sarandi. Conta ele que à tarde, depois de voltar da aula, acompanhava o pai em seu trabalho, aprendendo o ofício aos poucos, primeiro trabalhando apenas com a máquina elétrica para progressivamente aprender técnicas mais complexas, o que já inclui o uso da navalha para fazer barbas e acabamentos no corte de cabelo. Em conversas informais ele contou que quando era jovem não havia tantas possibilidades como "hoje em dia". Para comprar um tênis, uma calça jeans - necessidades ou caprichos de um jovem de 15 ou 16 anos - ele deveria trabalhar e adquiri-los com o seu próprio dinheiro. 
É um cálculo bastante racional ao estilo do sujeito de Alfred Schutz (1979), Joel avalia suas opções em relação ao seu campo de possibilidades (Velho, 2003), isto é, a sua realidade objetiva associada aos constrangimentos e estímulos culturais presentes em seu meio social. Ao conversarmos sobre as minhas escolhas pela Antropologia e a formação acadêmica, Joel re-avalia suas possibilidades de sucesso profissional e financeiro em relação à sua formação educacional, pensando sobre o que um jovem com o colegial completo poderia fazer de modo a lhe trazer o máximo de retorno em conformidade com a sua formação educacional. O ofício de barbeiro e cabeleireiro lhe pareceu uma boa opção, tendo em vista a possibilidade de aprender as artes de fazer com o próprio pai, sem um custo adicional de um curso técnico ou uma faculdade. Sua "cultura" é adquirida a partir do contato com seus clientes, conforme ele declara:

E o legal dessa profissão é que tu consegue assim, por exemplo, tem o professor Bernardo, com uma cultura fantástica, uma pessoa fantástica, tem um juiz que é esse que faz toda sexta comigo cabelo e barba. Esse é o legal da profissão, tu diferenciar várias culturas, pessoas de todos os níveis, deputados e tal. E isso é legal, que te abre um leque, porque às vezes é uma pessoa que não teve uma via cultural, que nem eu né. Estudar, né, antigamente não tinha essa via cultural de estudar. Com o que eu que me peguei? Eu me peguei com uma profissão que me leva a ter essa cultura, né. Se quiser falar de política comigo eu falo, se quiser falar de futebol comigo eu falo, qualquer área eu domino, né, um globo, eu não sei tudo, mas procuro entender o todo, justamente por essa diversidade de clientes.

Joel trabalhou na barbearia de seu pai até que este falecesse. Julgando pouco vantajoso continuar mantendo sozinho a barbearia do pai no bairro de Sarandi, Joel vendeu o estabelecimento e foi viajar pelo sul e sudeste do Brasil trabalhando e adquirindo experiência como barbeiro e cabeleireiro. Morou em Florianópolis, Rio de Janeiro e São Paulo antes de voltar a Porto Alegre. No retorno à capital do Rio Grande do Sul, foi trabalhar na Barbearia Fígaro, que de acordo com Joel é a mais antiga de Porto Alegre. Da mesma forma que Dona Geci, foi atraído por um anúncio de jornal que requeria um barbeiro. Dirigiu-se até a Fígaro, fez um teste que consistia em cortar o cabelo e fazer a barba de um cliente sob a supervisão do dono da barbearia, Seu João, e foi imediatamente contratado. 


\section{Rede de ingresso na profissão - Joel}
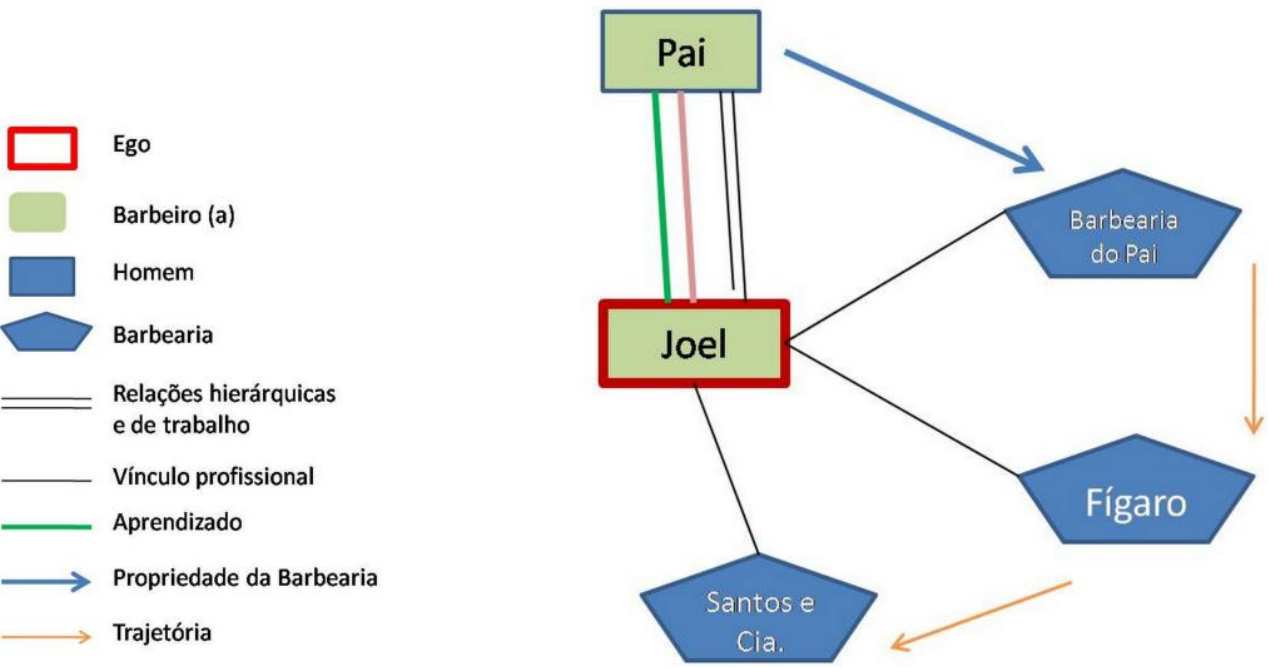

6. Ilustração de rede social - autoria do autor.

Há três anos está no Salão Santos e Cia., o que considera um progresso em sua carreira profissional, pois na Barbearia Fígaro era "comissionado", isto é, tributava uma porcentagem de seus ganhos ao dono do estabelecimento. No salão Santos e Cia., Joel é "locatário", ou seja, paga um preço fixo mensal pelo uso do espaço, orgulhando-se de que sua renda mensal excede em muito o valor fixo que paga ao dono do salão. Além disso, o Salão Santos e Cia é um "salão masculino", o que se define da seguinte maneira por Joel:

A barbearia mais antiga de Porto Alegre é aquela lá. Aquela lá ó! Fígaro! Eu trabalhava lá, eu comecei lá. Lá é a barbearia mais antiga que existe, eu até dei uma entrevista pro Teledomingo, pra menina Kelly, e ela me falou sobre as barbearias. Não é o caso da nossa: isso aqui já é um salão masculino, diferente de uma barbearia. Tu vai me perguntar: "Qual a diferença Joel?" Tem diferença! Numa barbearia tu faz um trabalho, assim é, mais básico: um corte de cabelo e uma barba. Aqui não, aqui tu faz umas luzes masculinas, aqui tu faz um cabelo desfiado numa navalha, tá entendendo? [...] Os cara lá [na barbearia] são bem cru. Tu chega lá e ele vai cortar teu cabelo e fazer a barba, não tem como lavar, não tem nada. Aqui não, tu chega aqui a gente corta, a gente lava, tu diz: "Pô Joel, o que tu acha de fazer umas luzes?”. Tem como, eu tenho um lavatório. É diferente, rola um sonzinho, e tal, tá, tá, tá, o papo é outro! 
As experiências de Joel são bastante relevantes para este trabalho porque ajudam a superar as dicotomias entre tradicional e moderno que se duplicam na oposição entre barbeiro e cabeleireiro. Por mais que Joel busque estabelecer diferenças entre as práticas de uma profissão e as de outra, na sua trajetória e experiência profissionais encontramse consubstanciados saberes e fazeres que sintetizam uma maneira específica de acomodar o ofício de barbeiro às transformações do mundo do trabalho - ou incorporar as técnicas e saberes dos cabeleireiros ao modus operandi dos barbeiros. O mesmo pode servir para uma reflexão sobre o espaço do "salão masculino", esta nova categoria que emerge a partir do trabalho de campo. Trata-se de uma categoria relevante para a pesquisa na medida em que representa expressões mais atualizadas de antigas formas de vida social no mundo urbano, mostrando que o ofício de barbeiro está longe de se extinguir, estando em processo de constante transformação.

\section{Considerações Finais}

Autores como José Sérgio Leite Lopes (1976) permitem lançar algumas questões sobre o tema desta pesquisa, o qual consiste nas transformações das relações de trabalho no mundo urbano. Um dos aspectos levantados pela sua análise diz respeito à “profissionalização do trabalhador" (Leite Lopes, 1976: 65). O autor situa a dimensão de ofício em um contexto pré-industrial em que a aprendizagem de uma arte ou saberfazer se dava em função da transmissão direta de conhecimento de pai para filho ou de mestre para aprendiz em um contexto doméstico, quando a aquisição de habilidades manuais estava ligada a anos de experimentação e prática, tal como ocorreu com Joel, que aprendeu a profissão aos poucos durante as tardes que passava na barbearia do pai.

Com a profissionalização do ofício, esta consequência da industrialização e do crescimento das cidades, haveria uma domesticação e especialização do saber do trabalhador que, ao contrário do antigo artesão de ofício, não possuiria mais a visão holista sobre o processo de produção no qual está inserido. As "artes de fazer" (De Certeau, 1994) de trabalhadores, como o barbeiro, sofreram um processo de profissionalização, no sentido de que hoje existem cursos técnicos em escolas e em outras instituições que legitimam a atuação de profissionais nessa área mediante a emissão de diplomas. No entanto, o saber-fazer de barbeiros e barbeiras continua a possuir características de artesania na medida em que este profissional trabalha sozinho 
em uma matéria que não é sua, mas sobre a qual ele mantém controle do início ao fim do processo de trabalho.

Tais tensões e contradições decorrentes das transformações de um ofício em profissão e das modificações das relações de trabalho em cidades como Porto Alegre não constituem uma novidade. Na medida em que as cidades brasileiras passam por processos de "higienização" e saneamento, são re-configuradas as atribuições do barbeiro, o qual era até inícios do século XX muitas vezes responsável pela execução de pequenos procedimentos cirúrgicos, sangrias e extração de dentes (Figueiredo, 1999: 272). Além disso, com o avanço do capitalismo industrial a divisão social do trabalho é intensificada, o que traz consequências como a delimitação de campos de atuação profissional e a regulamentação dos conhecimentos relativos às áreas de trabalho.

Hoje, ao menos em Porto Alegre, parece ser considerado relevante a profissionalização do barbeiro por meio de cursos técnicos como os que são oferecidos por instituições como o SENAC, onde o aluno aprende apenas a cortar cabelos e fazer barba, tendo disciplinas teóricas e aprendizado prático supervisionado que vai de seis a nove meses. Este foi o caso de Dona Geci e Seu Renato. No entanto, mesmo que ambos tenham realizado cursos profissionalizantes, uma parcela considerável - se não a mais relevante - de seu aprendizado se deu através de relações pessoais no contexto doméstico entre mestre e aprendiz, "madrinha" e "afilhada" ou entre irmãos. As experiências de Dona Geci, Seu Renato e Joel continuam a demonstrar a configuração de uma área profissional em constante transformação. Principalmente nos relatos de Joel é possível perceber jogos distanciamentos e aproximações relativas às práticas dos modernos cabeleireiros. Ao mesmo tempo, Joel nunca deixou de se considerar um barbeiro, principalmente quando lhe era requerido que desempenhasse tal papel.

Para concluir, destaco que barbeiros e barbeiras são detentores de um corpo de técnicas e saberes relativos à sua profissão que tensionam formas artesanais e industriais de trabalho. O saber-fazer, as técnicas, minúcias, "artes de fazer" e "artes de dizer" (Certeau, 1994) do barbeiro ou da barbeira remetem a um processo de aprendizado junto a barbeiros mais experientes, quando o neófito adquire o domínio sobre seu ofício no cotidiano por meio da incorporação de gestos e "técnicas corporais" (Mauss, 1974) que visam moldar uma determinada matéria, os pêlos do rosto humano.

O incremento da tecnologia e a popularização de equipamentos eletrônicos como a máquina de cortar cabelo incidem sobre as artes de fazer de barbeiros, mas estes estão sempre a criar "táticas e estratégias" (Certeau, 1994) para conciliar elementos 
considerados modernos ou tradicionais da profissão, engendrando novas maneiras de fazer durar o ofício de barbeiro na cidade. Ao mesmo tempo, estes profissionais são tributários de uma maneira muito específica de estetizar o outro que dura no tempo através da repetição quase exaustiva de gestos e sequências de gestos.

\section{Referências}

BENJAMIN, Walter. "O Narrador. Considerações sobre a obra de Nikolai Leskov". In: BENJAMIN, Walter. Magia e Técnica, Arte e Política. Ensaios sobre Literatura e História da Cultura. São Paulo: Brasiliense, 1996.

BOTT, Elizabeth. Família e rede social. Rio de Janeiro: Francisco Alves, 1976.

CERTEAU, Michel de. A invenção do cotidiano. vol. I. Petrópolis: Vozes, 1994.

CHEVALIER, Denis. "Des savoirs efficaces". In: Terrain, n.16, março de 1991. Paris: Ministère de la Culture et de la Communication; Fondation de la Maison des sciences de l'homme de Paris. p.5-11.

ECKERT, Cornélia; ROCHA, Ana L. C. da. O Tempo e a Cidade. Porto Alegre: Editora da UFRGS, 2001.

ECKERT, C.; ROCHA, A. L. C. da. "Narrar a cidade: experiências de etnografias da duração". In: Zita Rosane Possamai (Org.). Leituras da Cidade: Porto Alegre e seu patrimônio. Porto Alegre: Evangraf/ UFRGS, 2010. p. 85-108.

FIGUEIREDO, Bethânia. G. "Barbeiros e cirurgiões: atuação dos práticos ao longo do século XIX”. In: História, Ciências, Saúde - Manguinhos, v.6, n.2, jul.-out. Rio de Janeiro: Casa de Oswaldo Cruz, Fundação Oswaldo Cruz. p.277-91, 1999.

HALBWACHS, Maurice. A memória coletiva. São Paulo: Centauro, 2006.

LEITE LOPES, J.S. O vapor do diabo: o trabalho dos operários do açúcar. Rio de Janeiro: Paz e Terra, 1976.

MAUSS, Marcel. "Técnicas Corporais". In: MAUSS, Marcel. Sociologia e Antropologia. Volume II. São Paulo: EPU, 1974. p. 209-233.

OKIN, Susan Moller. "Gênero, o público e o privado." In: Revista Estudos Feministas, v.16, n.2. Florianópolis: Centro de Filosofia e Ciências Humanas/ Centro de Comunicação e Expressão da UFSC, 2008. p.305-332.

SILVA, Juremir Machado da. A noite dos cabarés: histórias do cotidiano de uma cidade grande. Porto Alegre: Mercado aberto, 1991.

SCHUTZ, Alfred. Fenomenologia e relações sociais. Textos escolhidos de Alfred Schutz. Rio de Janeiro: Zahar, 1979.

VELHO, Gilberto. Projeto e Metamorfose: antropologia das sociedades complexas. Rio de Janeiro: Jorge Zahar Ed., 2003.

Recebido em: 15/12/2011

Aprovado em: 28/03/2012 